\title{
Engendering Transitional Justice: Silence, Absence and Repair
}

\author{
Olivera Simic ${ }^{1}$
}

Published online: 22 December 2015

(C) Springer Science+Business Media Dordrecht 2015

Transitional justice is a growing field that responds to dilemmas over how successor regimes deal with (or should deal with) the human rights abuses of their authoritarian predecessors. In coming to terms with the past and establishing terms and conditions for the future, transitional justice encompasses accountability and responsibility, as well as healing, reconciliation, truth and conflict resolution.

This special issue grew out of a two-day symposium held in Coolangatta, Australia, in November 2014, organised by the Socio-Legal Centre, Griffith Law School, Griffith University, Australia. The symposium brought together experts concerned with transitional justice studies to consider new ways in which gender needs be rethought and perhaps reinterpreted, in the context of societies that deal with massive human rights abuse. The symposium was an intense and close engagement, where scholars from the fields of human rights, transitional justice, anthropology, psychology, and peace and conflict studies presented their work and received constructive feedback from their colleagues. Five papers that were part of the symposium proceedings are featured in this special issue, covering a broad spectrum of interrelated topics, and highlighting debates in the field of transitional justice that are often overlooked and underdeveloped in the literature.

In accordance with the theme of the symposium, the articles in this special issue are unified by the topic of 'Engendering Transitional Justice' and the crosscutting themes of 'Silence, Absence and Repair'. The themes that emerged during the symposium add new facets to the already diverse spheres of research pertaining to gender and transitional justice, which, although occupying a growing space in academia, still remain under-theorised and under-researched.

Given the advances - and the setbacks - that have occurred in the realm of gender perspectives in transitional justice during the last decade, there is a need to take stock of how far the field has progressed. By gathering reflections from scholars working within a variety of processes aimed at gender justice, this issue addresses some conceptual

Olivera Simic

o.simic@griffith.edu.au

1 Griffith Law School, Brisbane, QLD, Australia 
silences in the field of transitional justice. It builds on valuable scholarship on gender in transitional justice, but departs from the standard approach often focused on certain women's experiences. The articles include case studies from Africa, Asia Pacific, Latin America and Eastern Europe, which assess efforts to achieve justice for gender-based violations, analyse their efficacy and question how successfully they have engaged with both female and male survivors' experiences. The aim of this issue is to inform future gender justice efforts by identifying gender-based themes that have been addressed so far, and to constructively critique those that have been absent and silences within the scholarly literature.

By analysing how countries like South Africa, Northern Ireland, East Timor, Peru and Bosnia and Herzegovina, to name a few, come to terms with their violent pasts, the authors take a broader view on the gendered impact of transitional justice, incorporating, but going beyond, a focus on violence against women. Efforts to integrate gender perspectives in transitional justice processes have come as a result of a neglect of women's experiences during and after conflict. Understandably, securing justice to women has been of paramount importance to feminist scholars, who explore the ways in which transitional justice mechanisms can and should work for women. An impressive volume of literature has been produced over the past 15 years that looks at some of the challenges women face when it comes to trials, reparations, truth commissions and other forms of truth-seeking (Franke 2005; Campbell 2007; Rubio-Marin 2009; Rimmer 2010a; Kent 2012).

Despite the richness of research on the subject matter so far, the articles in this issue suggest innovative ways of utilising what the field of transitional justice has acquired in the process of examining how societies deal with past abuses to meet victims' legitimate expectations of justice, truth and reparation. The authors here turn their attention to investigate other expressions of gendered injustices, such as structural inequalities, citizenship, constructions and hierarchies of victimhood, the role of masculinities and the role of narratives (verbal and non-verbal) in transitional justice processes. This collection aims to fill a gap in the scholarship and bring new and original research that specifically addresses three key topics: silence (i.e. of certain, less 'ideal', victims), absence (i.e. of masculinity analysis) and repair (individual and communal) for gender injustices.

This special issue aims to influence the way we think about 'gender' in a global context. For example, although transitional justice scholars take gender on board, even they can and do easily slip from gender to 'women' (Porter, this issue) and reflect upon women's experiences only. As Rooney argues, 'Gender has come to mean solely a reference to 'all women' that fails to comprehend structural inequalities between women and within social groups in conflicts' (Rooney 2007). Ni Aoláin and Rooney (2007) advocate for greater intersectionality and cultural sensitivity of gender issues. However, it still remains a challenge in transitional justice scholarship to embrace gender analysis that is not focused on women solely and fixed on certain women ('authentic' victims) and certain female victims' experiences of violence (sexual).

Ideally, as Porter argues in this issue, 'talk of gender should keep the focus on women and men'. Still, the experiences of men, although dissimilar in many ways to women's experiences of war and post-war, remain almost excluded from academia and public discourse (Zarkov 1997; Zarkov 2001; Simić 2015). Apart from being seen as perpetrators or heroes, males have attracted very little attention 
as victims or as peacebuilders and agents of positive change in the aftermath of massive human rights abuse.

The authors in this issue point to the unequal position of gender in society but also problematise the often homogenously used notion of women and men in academia, which neglects different treatment in transitional justice processes based on race, ethnicity and/or class. The articles problematise the 'false dichotomies' (Tabak 2011) on which the transitional justice paradigm is premised, such as victim/perpetrator and conflict/post-conflict. Engendering transitional justice should be interpreted as acknowledging and addressing the different wartime experiences of men and women, and the challenges both genders face in the aftermath of war or dictatorship, irrespective of their ethnic or religious and any other fixed identity. It has been long acknowledged that women who live through war and conflict 'do not fall into a single group' (Meintjes et al. 2002). Yet, it seems that women often become generalised and represented as such.

Dismantling narratives of men as exclusively perpetrators and women as exclusively victims is important not only to prevent reinforcing and perpetuating gender stereotyping, but also to understand the breadth and depth of various forms of dealing with traumatic experiences. However, the challenge remains how to engage with experiences of both genders, but not advance and argue for one gender over the other or relativise them. In his 2007 exploratory essay, Brandon Hamber noted that studies on masculinity and transitional justice were 'all but non-existant'. Hamber in this issue reflects on the past decade and examines the current state of studies of masculinity in transitional justice literature by providing a comprehensive overview of scholars' (lack of) engagement with an issue.

Hamber notes that masculinity as an issue in transitional justice could still at best be described as 'emergent'. He highlights the marginal nature of the concept of masculinity in transitional justice studies and shows that masculinity is not a concept overwhelmingly correlated with the mention of gender. Although scholarship is emerging in the masculinity study literature on conflict zones, as Cahn and Ni Aoláin (2010) argue, 'post-conflict societies present a unique and under-analysed site of examination for masculinities'.

Similar to the fixation on female victims of sexual violence in war, the focus of scholarly attention to male victims' experience in war is largely focused on male-tomale wartime sexual violence (DelZotto and Jones 2002; Oosterhoff et al. 2004; Stemple 2009; Sivakumaran 2007). Hamber argues that while this issue needs attention, we ought to approach it with care, as we should not conflate sexual violence against men as being about the study of masculinity. Also, Hamber makes the point that 'the limited work that has been done in the peacebuilding and transitional justice field on masculinity is leaning too heavily in that direction at the expense of other concerns' (this issue). Masculinity, according to him, is a wider frame and sexual violence against men needs to be seen within that frame; otherwise, we risk replicating what happened with the hypervisibility of rape against women, and miss the wider context (socioeconomic, political). Hamber's concern is that our focus on sexual violence against men in discussions of masculinity can deflect attention away from the crucial task of exploring 'the ability of violent masculinities to linger and transform' after conflict is over.

Some feminist scholars recognise the danger of a 'centric fixation' on sexual violence against women in war (Cahn and Ni Aoláin 2010; Henry 2014; Engle 2005; 
Engle 2014). They claim that the almost exclusive attention given to sexual violence against women diverts attention from wider women's concerns such as socioeconomic rights, or domestic violence in the aftermath, and possibly contributes to 'problematic hierarchies of victimisation' (Henry 2014). The tendency to reduce women to victims, and then to victims of a specific category of violence, also risks reinforcing and perpetuating gender stereotypes, rather than identifying and challenging them (Buckley-Zistel and Zolkos 2011). Such a focus also 'seems to have blocked any consideration of other gender-based violence' (Rimmer 2010b) including male-to-male wartime violence. Sexual torture leaves males, as is the case with female victims, with lifelong trauma. However, it triggers some specific gender traumas that are unique to men, such as feeling emasculated, feminised and stripped of a sense of manhood. It is very important to understand how the performance of masculinities in a wartime context contributes not only to male-on-male violence but also to its denial and cover up (Sigsworth and Valji 2011; Simić 2015).

How men are located as victims of war in transitional justice discourses and practices is still a novelty and needs to be unpacked. The intersectional operations of patriarchy in conflict and the disparity in benefits and costs experienced by men who are differentially positioned in structural terms, for instance, of class, sect and race, in the political regime in transition, are also absent from academic analyses (Rooney 2007). An awareness of the impact of these different types of masculinities is essential also for a successful transition to sustained peace (Gallagher and Hamber 2015).

The article by Elisabeth Porter affirms the importance of telling stories and notes the significance of silence within transitional justice narratives. Stories told about violence, trauma and loss inform knowledge of post-conflict societies; they provide us with a context and a life narrative of the storyteller. Porter's article outlines a critical narrative theory of transitional justice that confirms the importance of narrative agency in telling or withholding stories. It affirms the importance of storytelling by men and women as a way to explain differentiated gender requirements within transitional justice processes. Second, it examines gendered differences in the ways that women are silenced by shame, or choose silence to retain self-respect, or how some men and women view silence as a strategy of survival. Third, it argues that compassionate listening recognises victims' selfhood in ways that potentially are healing, restoring the narrator's sense of self.

Peoples' stories may be a stimulus for exploring what prevents positive peace to flourish and to unravel alternative answers to difficult questions implicated in the relationship between justice, peace and reconciliation (Porter 2015). Julie Mertus (2000) argues that, for survivors, it is important to tell their story; as without such acknowledgment, survivors feel forgotten, erased and invisible. Bufacchi (2013) states that without first-person narratives and their recognition and legitimisation as epistemologically and philosophically valuable, 'our knowledge of violence would be seriously compromised'. Similarly, Brison (2013b) contends that personal narratives of oppression and victimisation can facilitate greater 'emphatic concern' and can play a critical role in our understanding of 'what justice requires'. Still, as Phelps (2011) argues, in transitional societies, we do not know much about how such stories operate, in particular, whether they are transformative and constructive to the peacemaking processes. 
While silence may be a vital strategy deployed to make a shared life possible (Eastmond and Selimovic 2012), if stories are not communicated and validated, reparation for harm suffered risks remaining unclaimed. As de Greiff (2006) argues, some elements of reparation, either symbolic or material, should be present; otherwise, restoration is deficient. Reparations are essential, not only because they serve to acknowledge past violations but also because they serve as a public commitment to respond to the lasting impact of those violations (Magarell 2003).

The article by Lia Kent further probes the silencing of stories and first person narratives and analyses how and why some gendered narratives have been excluded while others have been encouraged. Feminist scholars have questioned the issue of gendered citizenship and how transitional justice mechanisms influence the incorporation of citizens into the political community in states in transition (O'Rourke 2012). Kent explores the relationship between truth commissions and gendered citizenship through a case study of Timor-Leste. She examines how, 10 years after the Commission for Reception, Truth and Reconciliation (CAVR) completed its work, women's citizenship remains constrained by, and negotiated within, deeply gendered narratives of nation-building that are informed by historical experiences of the resistance struggle.

The power of these narratives - which foreground heroism rather than victimisation - underscores the need to situate truth commissions as part of an ongoing politics of memory. Political elites do not have a monopoly over this politics, however, and the continued marginalisation of sections of society within official narratives is providing an impetus for alternative truth-telling efforts, which seek to broaden available perspectives in the past in the public sphere. By promoting new narratives of women's experiences of the conflict, these projects might be understood as attempts to negotiate and transform gendered conceptions of citizenship in the present and for the future.

The article by Wendy Lambourne and Vivianna Rodriguez Carreon examines the continuity of harms and traumas experienced by women, before, during and after war and other mass violence. Lambourne and Rodriguez Carreon use the four key pillars of transitional justice identified by the United Nations as a framework to analyse how these harms are addressed in the context of criminal prosecutions, truth commissions, reparations and institutional reform. They conclude that a gender-transformative approach to transitional justice that focuses on transforming psychosocial, socioeconomic and political power relations in society is needed in order to attain human rights for women and to build a sustainable peace. Female victims of wartime rape often experience a 'continuum of violence' (Cockburn 2004; Sigsworth and Valji 2011), becoming victims of domestic violence in the aftermath of war.

Recently, local media quoted a woman who was sexually abused while she was a teenage prisoner during the war in Bosnia and Herzegovina $(\mathrm{BiH})$, 'I spent twenty days in a detention camp, where I survived rape. The abuse during the marriage, both physical and psychological, lasted longer' (Sorguc 2015). A local women's organisation, which supports woman victims of domestic violence, reported that $90 \%$ of women who seek help were once victims of wartime sexual abuse (Sorguc 2015). Male war veterans, on the other hand, are more at risk of committing suicide in the transitional, post-conflict time (Džidić 2012). Still, while violence against by women is ongoing and happens in peacetime, in war and post-conflict, it is not viewed as a 
politically significant issue to be acted upon or a human rights violation, except in 'some cases of rape in wartime' (Brison 2013a).

Lambourne and Rodriguez Carreon argue that a gender-sensitive, gender-responsive or even gender-inclusive approach to transitional justice is insufficient and inadequate to describe or explain the engagement of women in transforming their lives after mass violence, and the engagement required by men in that process. The authors argue instead for a gender-transformative approach to transitional justice that focuses on transforming psychosocial, socioeconomic and political power relations in society, as a means to attaining human rights for women and building sustainable peace. The adoption of a 'transformative justice' approach with a view to placing greater emphasis on, inter alia, structural violence and local agency as part of the transitional justice process has been suggested as an alternative to 'transition paradigm' (Sharp 2014).

The article by Olivera Simić analyses what it takes to conduct feminist and sensitive research on the silences surrounding certain female victims' experiences of wartime rape. The condemnation of wartime sexual violence as a gross violation of human rights has received widespread support in academia, international law, as well as in celebrity activism, mass media reporting and non-governmental and governmental initiatives. However, while rape and other forms of sexual violence have attracted considerable local and international attention, Simić argues that this recognition is predicated on premises of an 'ideal', 'desirable' and 'popular' victim - a victim who belongs to a nation that is perceived as innocent, a true victim attacked by perpetrator/ aggressor nation. Other victims are shunned, largely ignored, marginalised and invisible; these victims of sexual violence are absent not only from international law paradigms but also academia (Buss 2009). Due to the complex politics of victimhood, researchers' attention is often focused on certain victim subjects who acquire the 'rape victim identity' (Zarkov 1997). Their analysis and findings have contributed to increasing the social visibility of some categories of victims, while other victims have stayed largely 'invisible and unrecognised' (Lindgren and Nikolic-Ristanovic 2011).

This article is informed by Simić's experiences of undertaking research in wartime rape in the ethnically and politically divided country of Bosnia and Herzegovina. Simić uses the example of her recent study of silenced victims to explore methodologies, surrounding transitional justice research that involve critical examination of difficult topics and raise a number of ethical and methodological issues for both the participants and the researchers. While empirical research has been a facet of the studies produced in the field, Simić argues that researchers' accounts of undertaking research in politically sensitive environments are largely missing from published books and research reports. Traditionally, in transitional justice, as in other social science studies, researchers are concerned primarily with participants' wellbeing and experiences. Simić suggests that there is a need to pay more attention to researchers' accounts and experiences in the field. She argues that the researcher's profile and positionality directly affect the fieldwork, and that fieldwork is a dialogical process, which is structured by the researcher and the wider political processes in the country. The researcher's identity, as well as participants, has multilayered consequences in the process of undertaking research.

It has been acknowledged that the implementation of transitional justice mechanisms is too often instrumentalised and mainstreamed, embraced by the UN, academic journals and consultant experts (Arriaza and Roht-Arriaza 2008). Sensibility to 
sociocultural factors and a long-term focus on transition processes are needed to comprehend how individuals and communities continuously refashion their gendered worlds in ways that are instrumental to attain war-related justice. Such a conception of justice goes beyond and remains broader concept than transitional justice itself (Duthie 2014).

In this special issue, only certain pertinent empirical and conceptual issues have been covered in the hope that the findings and questions raised will stimulate further research. The reality that transitional justice will 'always be both incomplete and messy' (Franke 2005) should not be seen necessarily as a disadvantage: often, the messiness can open new spaces for thinking about other ways of representation, in this case, of gender and its absences and silences.

\section{References}

Arriaza L, Roht-Arriaza N (2008) Social reconstruction as local process. IJTJ 2(2):152-172. doi: 10.1093/ijtj/ijn010

Brison SJ (2013a) Justice and gender-based violence. Revue Internationale de Philosophie 3:259-275

Brison SJ (2013b) "On empathy as a necessary, but not sufficient foundation for justice (A Response to Slote)." In: Amaya A, Lai HH (eds) Law, virtue and justice. Hart Publishing, Oxford, pp 303-309

Buckley-Zistel S, Zolkos M (2011) Gender in transitional justice. Palgrave Macmillan, New York

Bufacchi V (2013) Knowing violence: Testimony, trust and truth. Revue Internationale de Philosophie 3:277291

Buss D (2009) Rethinking rape as a weapon of war. Feminist Legal Studies 17(2):145-163

Cahn N, Ni Aoláin FD (2010) Gender, masculinities and transition in conflicted societies. New England Law Review 44(1):101-123.

Campbell K (2007) The gender of transitional justice: Law, sexual violence and the International Criminal Tribunal for the Former Yugoslavia. ITJT 1(3):411-432. doi: 10.1093/ijtj/ijm033

Cockburn C (2004) "The continuum of violence: A gender perspective on war and peace." In: Giles W and Hyndman J (eds) Sites of violence: Gender and conflict zones. Berkeley, University of California Press, California, pp $24-44$

de Greiff P (2006) "Reparations and development." In Boraine A, Valentine S (eds) Transitional justice and human security. International Center for Transitional Justice, Cape Town.

DelZotto A, Jones A (2002) Male-on-male sexual violence in wartime: Human rights' last taboo? Paper presented to the Annual Convention of the International Studies Association. ISA: New Orleans, LA, 2327 March 2002. http://adamjones. freeservers.com/malerape.htm. Accessed 5 May 2014

Duthie R (2014) “Transitional justice, development, and economic violence.” In Sharp DN (ed) Justice and economic violence in transition. Springer, New York, pp 165-201

Džidić D (2012) BiH i dalje živi sa posljedicamam rata. Balkan Transitional Justice. http://www.balkaninsight. com/en/article/bih-i-dalje-zivi-s-posljedicama-rata. Accessed 12 April 2015

Eastmond M, Selimovic JM (2012) Silence as possibility in postwar everyday life. IJTJ 6(3):502-524

Engle K (2005) Feminism and its (dis)contents: Criminalizing wartime rape in Bosnia and Herzegovina. American Journal of International Law 99(4):778-816

Engle K (2014) “The grip of sexual violence: Reading UN Security Council Resolutions on Human Security." In Otto D, Heathcote G (eds) Rethinking peacekeeping, gender equality and collective security: An introduction. Palgrave Macmillan, New York, pp 23-47

Franke KM (2005) Gendered subjects of transitional justice. Columbia Journal of Gender and Law 15(3):813828

Gallagher E, Hamber B (2015) "Addressing the psychosocial needs of young men: The case of Northern Ireland." In Hamber B, Gallagher E (eds) Psychosocial perspectives on peacebuilding. Springer, Switzerland, pp 71-116

Hamber, B (2007) Masculinity and transitional justice: An exploratory essay. International Journal of Transitional Justice, 1(3), 375-390.

Henry N (2014) The fixation on wartime rape: Feminist critique and international criminal law. Social \& Legal Studies 23(1):93-111. doi:10.1177/0964663913499061 
Kent L (2012) Dynamics of transitional justice: International models and local realities in East Timor. Routledge, New York

Lindgren M, Nikolic-Ristanovic V (2011) Crime victims: International and Serbian perspective. OSCE. http://www.osce.org/serbia/85268?download=true. Accessed 20 April 2015

Magarell L (2003) Reparations for massive or widespread human rights violations: Sorting out claims for reparations and the struggle for social justice. Windsor Y.B. Access Just. 22:85-98

Meintjes S, Pillay A, Turshen M (eds) (2002) The aftermath: Women in post-conflict transformation. Zed Books, London

Mertus J (2000) "The truth in a box: The limits of justice through judicial mechanisms." In: An-Na'im A and Amadiume I (eds) The politics of memory: Truth, healing and social justice. Zed Books, New York, pp $142-150$

Ni Aoláin F, Rooney E (2007) Underenforcement and intersectionality: Gendered aspects of transition for women. ITJT 1(3):338-354. doi: 10.1093/ijtj/ijm031

Oosterhoff P, Zwanniken P, Ketting E (2004) Sexual torture of men in Croatia and other conflict situations: An open secret. Reproductive Health Matters 12(23):68-77. doi: 10.1016/S0968-8080(04)23115-9

O'Rourke C (2012) "Transitioning to what? Transitional justice and gendered citizenship in Chile and Colombia.” In: Buckley-Zistel S, Stanley R (eds) Gender in transitional justice. Palgrave MacMillan, New York, pp 136-160

Phelps TG (2011) The ethics of storytelling: A nation's role in victim/survivor storytelling. Ethical Perspectives 18(2):169-195. doi: 10.2143/EP.18.2.2116809

Porter E (2015) Connecting peace, justice and reconciliation Lynne Rienner, Boulder, Colo

Rimmer SH (2010a) Gender and transitional justice: The women of East Timor. Routledge, New York

Rimmer SH (2010b) Sexting the subject of transitional justice. Australian Feminist Law Journal 32:123-147

Rooney E (2007) Engendering transitional justice: Questions of absence and silence. International Journal of Law in Context 3(2):173-187

Rubio-Marin R (2009) The gender of reparations: Unsettling sexual hierarchies while redressing human rights violations. Cambridge University Press: Cambridge

Sharp DN (2014) Emancipating transitional justice from the bonds of the paradigmatic transition. IJTJ 9(1): $150-169$

Sigsworth R, Valji N (2011) "Continuities of violence against women in South Africa: The limitations of transitional justice." In: Buckley-Zistel S and Stanley R (eds) Gender in transitional justice. Palgrave Macmillan, UK, pp 115-135

Simić O (2015) "Wartime rape and its shunned victims." In Randall A (ed) Genocide and gender in the twentieth century: A comparative survey. Bloomsbury, Oxford, pp 237-257

Sivakumaran S (2007) Sexual violence against men in armed conflict. The European Journal of International Law 18(2):253-276

Sorguc A (2015) Domestic violence revives Bosnian women nightmares. BIRN, Switzerland. www. balkaninsight.com/en/article/domestic-violence-revives-ex-prisoners-wartime-nightmares/1440/3. Accessed 19 February 2015

Stemple L (2009) Male rape and human rights. Hastings Law Journal 60:605-647

Tabak S (2011) False dichotomies of transitional justice: Gender, conflict and combatants in Colombia. JILP 44:103-163

Zarkov D (1997) War rapes in Bosnia: On masculinity, femininity and power of the rape victim identity. Tijdschrift voor Criminologie 39(2):140-151

Zarkov D (2001) "The body of the other man: Sexual violence and the construction of masculinity, sexuality and ethnicity in Croatian media." In: Moser CON, Clark FC (eds) Victims, perpetrators or actors? Gender, armed conflict and political violence. Zed Books, London, pp 69-82 